\title{
PENERAPAN FLIPPED CLASSROM BERBASIS YOUTUBE DI PRODI MATEMATIKA UNTUK MENINGKATKAN KEMAMPUAN PEMECAHAN MASALAH MAHASISWA
}

\author{
Oleh \\ Muhammad Syahril Harahap ${ }^{1}$, Sartika Rati Asmara Nasution ${ }^{2}$ \\ ${ }^{1,2)}$ Institut Pendidikan tapanuli Selatan \\ ${ }^{1)}$ muhammadsyahrilharahap@gmail.com, \\ ${ }^{2)}$ sasartikaratiasmara_nasution@yahoo.com
}

\begin{abstract}
Abstrak
Rendahnya kemampuan pemecahan masalah di Institut Pendidikan Tapanuli Sealatan Program Studi Pendidikan Matematika telah terlihat secara kuantitatif saat observasi kelas di IPTS. Sehubungan dengan keterkaitan tersebut maka penting mengembangkan pembelajaran yang efektif untuk kemampuan pemecahan masalah matematis. Pemecahan masalah matematis disini adalah pemecahan masalah soal soal tidak biasa (Non Routine) guna bekal dalam persaingan global. Salah satu pembelajaran yang sesuai jika ditelusuri secara teoritis adalah pembelajaran Flipped Classroom sebab pembelajaran ini akan memberikan sentuhan baru berupa variasi mengajar menggunakan media pembelajaran berupa video pembelajaran online. Dalam hal ini youtube menjadi aplikasi pilihan yang tepat. Berangkat dari fenomena tersebut, target khusus yang ingin dicapai adalah ingin menyumbang pemikiran tentang bagaimana menciptakan pembelajaran yang efektif dalam meningkatkan kemampuan pemecahan masalah matematis mahasiswa yang masuk dalam kategori pemikiran tingkat tinggi (High Order Thinking). Metode yang digunakan adalah quasi eksperimen semu. Dengan hasil observasi penerapan model pembelajaran flipped classroom oleh peneliti di prodi matematika IPTS telah dilaksanakan sebesar 3,8 yang jika dikategorikan adalah sangat baik. Kemudian kemampuan pemecahan masalah mahasiswa juga ikut meningkat dengan meningkatan dari rata rata 51.6 menjadi 81,6 serta banyaknya aktifitas-aktifitas positif yang terjadi setelah dilaksanakannya model pembelajaran ini.
\end{abstract}

Kata kunci: Flipped Classroom berbasis Youtube, Video Pembelajaran Digital, Geometri, Pemecahan masalah

\section{PENDAHULUAN}

Rekomendasi National Council of

Teachers of Mathematics (NCTM, 2000) menyatakan bahwa: "Pemecahan masalah harus menjadi fokus pada pelajaran matematika di sekolah". Hal senada tentang pentingnya pemecahan masalah disampaika Pehkonen yang mengkategorikan pentingnya pemecahan masalah dalam 4 kategori; a) pemecahan masalah akan mengembangkan kemampuan kognitif, b) pemecahan masalah mendorong terciptanya kreatifitas, c) pemecahan masalah adalah bagian dari proses pengaplikasian matematika dan d) pemecahan masalah akan memotivasi peserta didik belajar matematika (Laine dkk, 2012).

Kenyataan di lapangan menunjukkan bahwa hasil pembelajaran matematika dalam aspek pemecahan masalah matematika masih rendah. Hasil survei peneliti (tanggal 2 Juli 2018) berupa pemberian tes diagnostik kepada mahasiswa semester III Prodi Pendidikan Matematika Institut Pendidikan Tapanuli Selatan menunjukkan bahwa $70 \%$ dari jumlah mahasiswa mengalami kesulitan dalam menyelesaikan soal dalam bentuk pemecahan masalah. Masalah rendahnya kemampuan pemecahan masalah diatas setelah ditelusuri dengan wawancara terhadap mahasiswa dan beberapa dosen sejawat. Terungkap bahwa sebagian besar mahasiswa bosen dengan model pembelajaran yang hanya diskusi biasa dan monoton selain itu mereka juga mengharapkan materi yang disajikan agar lebih menarik dan mudah dipahami. Dari hasil wawancara ini jelas hal terlihat penyebab rendahnya kemampuan mahasiswa. sehingga solusi pembelajaran yang dapat meningkatkan kemampuan pemecahan mahasiswa. Model pembelajaran yang digunakan selayaknya dapat membantu mahasiswa dapat memecahkan masalahnya secara mandiri. Trianto menyebutkan di lain pihak secara empiris berdasarkan analisis penelitian terhadap rendahnya hasil belajar peserta didik yang disebabkan dominannya proses pembelajaran konvensional. Pola pengajaran terlalu banyak didominasi oleh dosen, khususnya dalam transformasi pengetahuan kepada anak didik (Trianto, 2009). Hal ini mengakibatkan mahasiswa merasa jenuh dan keinginannya untuk lebih mendalami matematika terbuang jauh sehingga nantinya pemecahan masalah matematis mahasiswa rendah. Sehingga, solusi yang mungkin adalah memberikan strategi pembelajaran yang tepat, salah satunya adalah flipped classroom.

Flipped classroom merupakan strategi yang dapat diberikan oleh pendidik dengan cara meminimalkan jumlah instruksi langsung dalam praktek mengajar mereka sambil memaksimalkan interaksi satu sama lain. Strategi ini memanfaatkan teknologi yang menyediakan tambahan yang mendukung materi pembelajaran bagi mahasiswa yang dapat diakses secara online (Jenkins dkk, 2007). Metode ini mengarah kepada 
pengembangan pengetahuan prosedural yang sangat penting untuk pemecahan masalah matematis.

\section{Kemampuan Pemecahan Masalah Matematis}

Pemecahan masalah adalah satu

kemampuan yang sangat penting. Memecahkan masalah artinya mampu dengan baik memahami, merencanakan, melakukan dan menyimpulkan suatu masalah (soal) yang tidak biasa. Untuk memecahkan suatu masalah matematika ada beberapa strategi yang dapat digunakan bergantung masalah yang akan dipecahkan. Namun, ada strategi pemecahan masalah yang bersifat umum yaitu yang disarankan oleh George Polya. Menurut Polya, untuk memecahkan suatu masalah ada empat langkah yang dapat dilakukan, yakni:

1. Memahami masalah, Kompetensi mahasiswa pada langkah ini adalah : menentukan apa yang tidak diketahui? apa datanya? apa kondisinya? apakah kondisi tersebut cukup atau berlebihan atau saling bertentangan?

2. Merencanakan pemecahannya, Kompetensi mahasiswa pada langkah ini adalah menentukan perencanaan solusi yang mungkin dengan mengkaitkan antara pengalaman belajar yang sudah dimiliki.

3. Melaksanakan rencana, kegiatan yang dapat dilakukan pada langkah ini adalah: menjalankan prosedur yang telah dibuat pada langkah sebelumnya untuk mendapatkan penyelesaian.

4. Memeriksa kembali prosedur dan hasil penyelesaian, kegiatan yang dapat dilakukan pada langkah ini adalah: menganalisis dan mengevaluasi apakah prosedur yang diterapkan dan hasil yang diperoleh benar, apakah ada prosedur lain yang lebih efektif, apakah prosedur yang dibuat dapat digunakan untuk menyelesaikan masalah yang sejenis, atau apakah prosedur dapat dibuat generalisasinya (Polya, 1957).

\section{Flipped Classroom Berbasis Youtube}

Penggunaan pembelajaran konvensional saat ini telah memberikan kejenuhan. Sehingga flipped classroom adalah salah satu solusi. Menurut Johnson Flipped classroom merupakan strategi yang dapat diberikan oleh pendidik dengan cara meminimalkan jumlah instruksi langsung dalam praktek mengajar mereka sambil memaksimalkan interaksi satu sama lain. Strategi ini memanfaatkan teknologi yang menyediakan tambahan yang mendukung materi pembelajaran bagi mahasiswa yang dapat diakses secara online (Johnson and Renner, 2012). Sesuai dengan hal tersebut Jenkins et al (2007) menyatakan "Flipped learning pedagogy stems from the premise of inquiry-based and egalitarian philosophy: with the growing access to vast information through the internet, the traditional model of teacher as the sole steward of knowledge has become obsolete".

Namun ada 4 hal yang perlu perhatikan sebelum melaksanakan flipped classroom, (Moran,
2015) seperti: apakah desain flipped classroom yang dibuat digunakan untuk mahasiswa; apakah flipped classroom yang dibuat untuk lebih dari satu kali pertemuan; apakah sudah memilih konten yang cocok untuk digunakan pada flipped classroom; dapatkah mahasiswa mendemonstrasikan apa yang telah mereka lihat dan pelajari dari konten yang disediakan; apakah dalam pembelajaran flipped classroom juga dilakukan pendekatan proaktif dalam manajemen kelas. Adapun alasan untuk melakukan flipped classroom menurut Kathleen P. Fulton (2012), seperti: mahasiswa memahami materi dengan langkah mereka masing-masing; mengerjakan "latihan" di kelas membuat dosen lebih mengetahui kemampuan pemahaman mahasiswa baik kesulitan yang dialami maupun gaya belajar mahasiswa; dosen dapat menyesuaikan dan memperbarui kurikulum serta menyediakannya bagi mahasiswa selama 24 jam setiap harinya; mahasiswa dapat mengakses pembelajaran beberapa dosen dengan keahliannya masingmasing; perkembangan flipped classroom yang dilakukan oleh dosen dilihat secara profesional dengan saling melihat video antar dosen dan pembelajarannya; waktu di kelas dapat digunakan secara lebih efektif dan kreatif; orang tua dapat melihat soal latihan; pencapaian mahasiswa yang meningkat, sehingga menarik dan menjanjikan untuk matematika ke level yang lebih tinggi; mempelajari teori yang mendukung pada pendekatan-pendekatan yang baru; dan manfaat dari menggunakan tehknologi adalah fleksibel dan sesuai untuk pembelajaran abad 21. Mengingat flipped classroom ini sangat sesuai untuk abad 21 maka jika disandingkan dengan sesatu yang sangat trend saat ini akan dirasa sangat pantas yaitu aplikasi video youtube. Berdasarkan pembahasan diatas maka pembelajaran flipped classroom menggunakan youtube adalah strategi pembelajaran antraktif yang dapat diberikan oleh pendidik dengan cara meminimalkan jumlah instruksi langsung dalam praktek mengajar mereka sambil memaksimalkan interaksi satu sama lain melalui youtube (Wikipedia)

\section{METODE PENELITIAN}

Penelitian ini menggunakan eksperimen semu (Quasi Eksperimental Design) Peneliti menggunakan desain penelitian yang berbentuk one group pretest-posttest design menggunakan satu jenis perlakuan. Penelitian ini akan dilaksanakan di Program Studi Pendidikan Matematika Institut Pendidikan tapanuli Sealatan. Adapun alasan penulis menjadikan lokasi ini sebagai tempat penelitian disebabkan karena perlunya peningkatan kemampuan pemecahan masalah matematis mahasiswa. Dikuatirkan jika tidak diatasi maka akan memperburuk mutu lulusan nantinya.

Populasi dalam penelitian ini adalah seluruh subjek penelitian yaitu seluruh mahasiswa semester III Program Studi Pendidikan 
Matematika Institut Pendidikan tapanuli Selatan yang berjumlah 50 mahasiswa. Sampel diambil dengan teknik total sampling mengingat jumlah mahasiswa semester III adalah 50 orang karena apabila kurang dari 100 lebih baik diambil semua (Arikunto, 2013).

Instrumen penelitian merupakan alat untuk memperoleh data atau informasi yang diperlukan untuk menguji hipotesis. Adapun instrumen yang digunakan dalam penelitian ini adalah :

a. Tes Kemampuan Pemecahan Masalah

Matematis (TKPMM)

Instrumen tes kemampuan belajar digunakan untuk menilai kualitas hasil belajar mahasiswa setelah selesai pembelajaran geometri dengan menggunakan RPS (Rancangan Pembelajaran Semester) yang menggunakan pembelajaran flipped classroom berbasis Youtube. TKPMM Geometri ini berbentuk essay dikembangkan oleh peneliti dengan mengacu pada CPMK mata kuliah yang telah dibuat.

b. Lembar Pengamatan

Untuk mengetahui kualitas proses, dilakukan pengamatan terhadap: aktivitas mahasiswa, kemampuan dosen mengelola pembelajaran, respon mahasiswa. Pengamatan dilakukan dengan menggunakan lembar pengamatan yang terdiri dari lembar aktivitas mahasiswa, lembar kemampuan dosen mengelola pembelajaran, lembar respon mahasiswa.

- Lembar observasi aktivitas mahasiswa.

Instrumen ini digunakan untuk mendapat data tentang aktivitas mahasiswa selama berlangsungnya flipped classroom berbasis youtube.

- Lembar observasi kemampuan dosen mengelola pembelajaran

Instrumen ini digunakan untuk mendapatkan data tentang kemampuan dosen dalam menetapkan skenario pembelajaran flipped classroom berbasis youtube.

Pengumpulan data merupakan hal terpenting dalam penelitian, karena sedikitnya ada kesalahan dalam penelitian akan sangat berpengaruh terhadap data yang diberikan oleh responden. Dalam penelitian ini maka data dikumpulkan secara observasi, dan tes. Observasi diupayakan dapat melihat bagaimana gambaran pelaksanaan pembelajaran Flipped Classroom berbasis youtube yang ditinjau dari aktifitas mahasiswa melalui observasi. Sedangkan Test adalah melihat bagaimana kemampuan pemecahan masalah mahasiswa sebelum dan sesudah menggunakan pembelajaran Flipped Classroom berbasis youtube.

Teknik analisis data yang digunakan dalam penelitian ini adalah menggunakan deskriptif. Analisis deskriptif bertujuan untuk melihat gambaran secara umum tentang pembelajaran Flipped Classroom berbasis youtube dan gambaran kemampuan pemecahan masalah matematis mahasiswa pada mata kuliah geometri. yang hasil dari masing masing item yang diteliti akan dikategorikan dengann kriteria tertentu.

\section{HASIL DAN PEMBAHASAN PENELITIAN Hasil Penelitian}

Penerapam model Pembelajaran Flipped Classroom terhadap kemampuan pemecahan masalah di Mahasiswa Semester VI Pendidikan Matematika IPTS dengan sampel yang 27 mahasiswa, diberikan pembelajaran dengan menerapkan model pembelajaran flipped classroom, dengan hasil sebagai berikut;

\section{Deskripsi Data Penggunaan Model Pembelajaran Flipped Classroom Di Semester VI Prodi Pendidikan Matematika IPTS}

Kegiatan dosen dalam pelaksanaan penggunaan model pembelajaran flipped classroom di Semester VI Prodi Pendidikan Matematika IPTS akan di di deskripsikan. Melalui data rekapitulasi lembar observasi dalam Lampiran 8 diperoleh nilai terendah 0 dan nilai tertinggi 1 . Pada penelitian ini terlebih dahulu akan disajikan gambaran model pembelajaran flipped classroom yang diterapkan di Prodi Pendidikan Matematika IPTS. untuk menjawab penelitian yang ada pada rumusan masalah. Adapun rekapitulasi data hasil penelitian dari lembar observasi yang diperoleh dari lapangan dapat dilihat pada tabel berikut:

Tabel 1

Rekapitulasi Data Hasil Observasi Pada Model Pembelajaran Flipped Classroom

\begin{tabular}{|c|l|c|c|c|c|}
\hline No & \multicolumn{1}{|c|}{ Indikator } & $\begin{array}{l}\text { obse } \\
\text { rver } \\
\mathbf{1}\end{array}$ & $\begin{array}{l}\text { Obse } \\
\text { rver } \\
\mathbf{2}\end{array}$ & $\begin{array}{l}\text { To } \\
\text { tal }\end{array}$ & $\begin{array}{l}\text { Rata } \\
\text { Rata }\end{array}$ \\
\hline $\mathbf{1}$ & $\begin{array}{l}\text { Menonton Video } \\
\text { Pembelajarn youtube } \\
\text { yang dapat diakses di } \\
\text { link } \\
\text { https://www.youtube.co } \\
\text { m/channel/UCXRuQRIs } \\
\text { G-HVZgBrFU0av- } \\
\text { A?view_as=subscriber }\end{array}$ & 2 & 2 & 4 & 4 \\
\hline $\mathbf{2}$ & Memberikan Pertanyaan & 3 & 2 & 5 & 3,3 \\
\hline $\mathbf{3}$ & Berdiskusi & 3 & 3 & 6 & 4 \\
\hline $\mathbf{4}$ & Memberikan Tugas & 2 & 2 & 4 & 4 \\
\hline
\end{tabular}

Berdasarkan pengumpulan data melalui lembar observasi tentang penggunaan model pembelajaran flipped classroom melalui indikator yang telah ditetapkan dengan mengajukan 10 aspek yang diamati, diperoleh nilai terendah 0 dan nilai tertinggi 1. Dengan bantuan aplikasi SPSS 22, diperoleh output sebagai berikut :

Tabel 4

Deskripsi Data Penggunaan Model

Pembelajaran Flipped Classroom Statistics

\begin{tabular}{|ll|r|}
\multicolumn{2}{|l|}{ Flipped_Classroom } & \\
\hline $\mathrm{N}$ & Valid & 10 \\
& Missing & 2 \\
Mean & & 3.8000 \\
Median & & 4.0000 \\
Mode & & 4.00 \\
\hline
\end{tabular}


Jika nilai rata-rata hasil penggunaan model pembelajaran flipped classroom tersebut dikonsultasikan dengan tabel kriteria penilaian, maka diperoleh nilai rata-rata 3,80 dalam kategori "sangat baik". Nilai rata-rata setiap indikator penggunaan model pembelajaran flipped classroom dapat diuraikan sebagai berikut:

a. Penggunaan model pembelajaran flipped classroom di Prodi Pendidikan Matematika IPTS untuk indikator menonton video mencapai nilai rata-rata 3,33. Apabila dikonsultasikan kriteria penilaian maka nilai tersebut berada pada kategori "sangat baik"

b. Penggunaan model pembelajaran flipped classroom di Prodi Pendidikan Matematika IPTS untuk indikator memberikan pertanyaan mencapai nilai rata-rata 4,00. Apabila dikonsultasikan kriteria penilaian maka nilai tersebut berada pada kategori "sangat baik".

c. Penggunaan model pembelajaran flipped classroom di Prodi Pendidikan Matematika IPTS untuk indikator berdiskusi mencapai nilai rata-rata 400. Apabila dikonsultasikan kriteria penilaian maka nilai tersebut berada pada kategori "sangat baik".

d. Penggunaan model pembelajaran flipped classroom di Prodi Pendidikan Matematika IPTS untuk indikator memberikan tugas mencapai nilai rata-rata 4,00. Apabila dikonsultasikan pada kriteria penilaian maka nilai tersebut berada pada kategori "sangat baik".

Deskripsi Kemampuan Pemecahan Masalah Matematis Mahasiswa Sebelum dan Sesudah Menggunakan Model Pembelajaran Flipped Classroom

Pada hasil pretest mahasiswa di Prodi Pendidikan Matematika IPTS yang berjumlah 27 orang, diperoleh nilai terendah 36,10 dan nilai tertinggi 77,70. Berdasarkan pengumpulan data kemampuan Pemecahan Masalah Matematis Mahasiswa sebelum menggunakan model pembelajaran flipped classroom dan selanjutnya data tersebut dianalisis dengan menggunakan aplikasi SPSS 22, maka diperoleh hasil analisis dalam output sebagai berikut.

Tabel 6

Mean, Median, Modus Tes Awal (Pretest) Kemampuan Pemecahan Masalah Matematis Statistics

Pretest

\begin{tabular}{|ll|c|}
\multicolumn{2}{c|}{ Pretest } \\
\hline $\mathbf{N}$ & Valid & 27 \\
& Missing & 0 \\
Mean & & 51.6037 \\
Median & & 50.0000 \\
Mode & 55.50 \\
\hline
\end{tabular}

Pada hasil tes awal (pretest) kemampuan Pemecahan Masalah Matematis Mahasiswa di Prodi Pendidikan Matematika IPTS, diperoleh nilai rata-rata (mean) 51,6 dan nilai tengah (median) 50,00 serta nilai yang paling sering muncul (modus) 55,50. Jika nilai rata-rata kemampuan Pemecahan
Masalah Matematis Mahasiswa tersebut dikonsultasikan dengan kriteria penilaian, maka kemampuan Pemecahan Masalah Matematis Mahasiswa sebelum menggunakan model pembelajaran flipped classroom pada materi geometri di Prodi Pendidikan Matematika IPTS berada dalam kategori "kurang".

Pada hasil posttest mahasiswa di Prodi Pendidikan Matematika IPTS yang berjumlah 27 orang, diperoleh nilai terendah 69,4 dan nilai tertinggi 91,6. Berdasarkan pengumpulan data kemampuan Pemecahan Masalah Matematis Mahasiswa sesudah menggunakan model pembelajaran flipped classroom dan selanjutnya data tersebut dianalisis dengan menggunakan aplikasi SPSS 22, maka diperoleh hasil analisis dalam output sebagai berikut.

Tabel 2

Mean, Median, Modus Tes Akhir (Posttest))

Kemampuan Pemecahan Masalah Mahasiswa Statistics

Posttest

\begin{tabular}{|ll|r|}
\hline N & Valid & 27 \\
& Missing & 0 \\
Mean & & 81.6519 \\
Median & & 83.3000 \\
Mode & & 83.30 \\
\hline
\end{tabular}

Pada hasil tes akhir (post test) kemampuan

Pemecahan Masalah Matematis Mahasiswa di Prodi Pendidikan Matematika IPTS, diperoleh nilai rata-rata (mean) 81,6519 dan nilai tengah (median) 83.3 serta nilai yang paling sering muncul (modus) 83,3. Berdasarkan perhitungan yang telah dilakukan, diperoleh nilai rata-rata (mean) 81,6519 dan nilai tengah (median) 83,30 serta nilai yang paling sering muncul (modus) 83,30. maka kemampuan Pemecahan Masalah Matematis Mahasiswa sesudah menggunakan model pembelajaran flipped classroom pada materi geometri di Prodi Pendidikan Matematika IPTS berada dalam kategori "sangat baik".

Pembahasan

Penelitian ini dilakukan sebanyak 3 kali pertemuan, pada pertemuan pertama memberikan pretest kepada mahasiswa kemudian menjelaskan materi geometri . Pada pertemuan kedua menjelaskan materi geometri tentang Luas permukaan kubus dan balok dengan model pembelajaran flipped classroom, dan pertemuan ketiga menjelaskan materi geometri tentang volume kubus dan balok, kemudian memberikan posttest kepada mahasiswa, namun sebelum memberikan pretest dan posttest terlebih dahulu soal yang akan dites diperiksa oleh pakar untuk divalidasi.

Model pembelajaran yang akan diterapkan disini adalah model pembelajaran Flipped Classroom. Dimana indikator yang digunakan peneliti dalam penerapan model pembelajaran flipped classroom memiliki 4 indikator yaitu 1) menonton video, 2) memberikan pertanyaan, 3) berdiskusi, 4) memberikan tugas. Adapun hasil 
penggunaan model pembelajaran flipped classroom yang diperoleh dari penelitian ini yaitu ;

- pada indikator pertama yaitu menonton video dapat dilihat bahwa pada lembar observasi semua kegiatan yang dilakukan dosen berjalan baik dan mendapatkan skor 4 dengan nilai 4,00 , hal ini terlihat juga dari rekam jejak video pembelajaran digital berbasis youtube yang mana hampir semua mahasiswa member respon positif dan ada beberapa interaksi dan pertanyaan seputar materi di youtube tersebut.

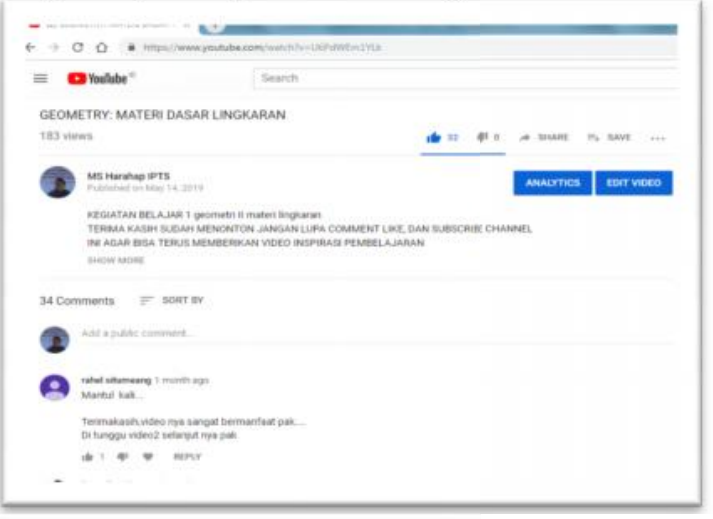

Gambar 1. Cuplikan respon mahasiswa yang menonton

video pembelajaran digital di youtube

- pada indikator kedua yaitu memberikan pertanyaan dapat dilihat pada lembar observasi semua kegiatan yang dilakukan dosen, tetapi ada salah satu poin pada indikator kedua padaa observer kedua pada lampiran lembar observasi yang tidak dilakukan dimana dosen atau peneliti tidak menununtun mahasiswa memberikan tanggapan mengenai materi yang diberikan sehingga skor yang diperoleh pada indikator ini yaitu 5 dengan nilai 3,33. Hal ini wajar saja sebab tidak mungkin mahasiswa langsung mngerti semua isi konten pembelajaran yang telah ia tonton sehingga hal hal yang kurang dipahami akan dilanjutkan dalam diskusi.

- pada indikator ketiga yaitu berdiskusi dilihat pada lembar observasi semua kegiatan yang dilakukan dosen berjalan dengan baik dan mencapai skor 6 dengan nilai 4,00. Saat berdiskusi ini semua berpusat kepada mahasiswa dosen hanya sebagai fasilitator.

- Pada indikator yang keempat yaitu memberikan tugas dapat dilihat pada lembar observasi semua kegiatan yang dilakukan dosen berjalan dengan baik dan mendapatkan skor 4 dengan nilai 4,00. Yaitu dengan mengerjakan test kemampuan pemecahan masalah matematis.

Adapun hasil rekapitulasi yang diperoleh dari pretest yang diberikan kepada mahasiswa sebelum menggunakan model pembelajaran flipped classroom di Semester VI Prodi Pendidikan Matematika IPTS adalah rata-rata 51,6034. Apabila dikonsultasikan kriteria penilaian maka nilai tersebut berada pada kategori "cukup", artinya pemecahan masalah mahasiswa pada indikator ini perlu ditingkatkan. Setelah pretest diberikan selanjutnya peneliti menerapkan pembelajaran flipped classroom dalam menyampaikan materi geometri nilai rata-rata yang diperoleh 81,6519 dimana itu artinya itu merupakan kriteria "sangat baik. Dari uraian di atas, kemampuan pemecahan masalah matematis mahasiswa pada materi geometri yang diajarkan setelah menggunakan model pembelajaran flipped classroom menunjukkan hasil yang memuaskan atau lebih baik bila dibandingkan dengan sebelum menerapkan model pembelajaran flipped classroom. Pembelajaran yang dirumah diberikan materi video pembelajaran digital berbasis youtube demi meningkatkan aktifitas positif mahasiswa sesuai dengan penelitian Harahap dan Fauzi (2018) yang mana pembelajaran berbasis web memberikan dampak yang baik terhadap peserta didiknya.

\section{SIMPULAN DAN SARAN Simpulan}

Berdasarkan hasil penelitian yang dilaksanakan, penulis menarik kesimpulan yang didasarkan pada hasil pengumpulan data. Adapun kesimpulan tersebut sebagai berikut :

1. Penggunaan model pembelajaran flipped classroom memperoleh nilai rata-rata 3,800 berada pada kategori "sangat baik" dan dapat disimpulkan bahwa penggunaan model pembelajaran Flipped Classroom di Program Studi Pendidikan Matematika IPTS semester VI sudah terlaksana dengan baik.

2. Kemampuan Pemecahan Masalah Matematis mahasiswa di Prodi Pendidikan Matematika IPTS sebelum menggunakan model pembelajaran flipped classroom mencapai nilai rata-rata 51,60 apabila dikonsultasikan maka kemampuan pemecahan masalah matematis mahasiswa berada pada kategori "kurang" sedangkan setelah penggunaan model pembelajaran flipped classroom kemampuan kemampuan pemecahan masalah matematis mahasiswa mencapai nilai rata-rata 81,6519. Apabila dikonsultasikan maka kemampuan pemecahan masalah matematis siswa berada pada kategori "sangat baik". Hal ini menunjukkan bahwa kemampuan koneksi matematis siswa sebelum dan sesudah menggunakan model pembelajarn flipped classroom mengalami peningkatan.

3. Penerapan Model Pembelajaran Flipped Classroom menggunakan konten video pembelajaran digital yang dibuat ke youtube memberikan aktifitas yang positif bagi mahasiswa, bahkan bagi masyarakat umum yang memerlukan informasi seputar materi tersebut. 


\section{Saran-saran}

Dari kesimpulan yang ditarik dari hasil penelitian dan implikasi penelitian yang dikemukakan di atas, maka penulis menyarankan hal-hal sebagai berikut :

1. Bagi mahasiswa, diharapkan agar lebih aktif dan giat belajar matematika guna meningkatkan kemampuan pemecahan masalah matematis mahasiswa yang lebih baik.

2. Kepada dosen, hendaknya lebih cermat dalam memilih atau menentukan metode, model, maupun strategi yang akan digunakan saat mengajar sehingga dapat membantu untuk mencapai tujuan yang diharapkan.

3. Kepada Ketua Program Studi Pendidikan Matematika selaku pembina instansi terkait diharapkan dapat meningkatkan dan memberikan masukan kepada dosen untuk lebih meningkatkan kemampuan mengajar dan memberikan penataran-penataran khususnya pada strategi pembelajaran matematika.

4. Kepada mahasiswa dan para peneliti ada kemungkinan kelemahan yang terjadi dalam pelaksanaan penelitian ini, maka perlu kiranya diadakan penelitian lebih lanjut dan yang ingin memperdalam penelitian tentang geometri dan dianjurkan untuk melihat dari sisi lain, sehingga kemampuan pemecahan masalah matematis siswa dapat ditingkatkan menjadi lebih baik lagi.

\section{UCAPAN TERIMAKASIH}

Terimakasih kepada Kemesristek Dikti melalui Simlitabmas dari DP2M DIKTI yang telah memberikan dana dalam penelitian ini untuk tahun 2019.

\section{DAFTAR PUSTAKA}

NCTM. (2000). Principles and Standards for School Mathematics. United States of America: The National Council of Teachers of Mathematics, Inc.

Laine, A., Näveri, L., Pehkonen, E., Ahtee , M., Hannula, M. 2012. Third-graders' problem solving performance and teachers' actions. Proceedings from the 13th ProMath conference, September 2011 (69-81). Umeå, UMERC.

Trianto. (2009). Mendesain Model Pembelajaran Inovatif-Progresif. Jakarta : Kencana Prenada Media Grup.

Jenkins, A., Healey, M., \& Zetter, R. (2007). Linking teaching and research in Departments and disciplines. York: Higher Education Academy.

Harahap, MS. Dan Fauzi, R (2018) Pengembangan Modul Pembelajaran Matematika Berbasis Web. 4(5)

Polya, G. 1957. How To Solve It. Peinceton University Press
Johnson, L. W., \& Renner, J. D. (2012). Effect of the flipped classroom model on a secondary computer applications course: Student and teacher perceptions, questions and student achievement (Unpublished doctoral dissertation). University of Louisville, Louisville, KY

Moran, Clarice M., Carl A. Young. (2015). Questions to consider before flipping, The Phi Delta Kappan, 97(2) 42-46.

Fulton, Kathleen P. 2012. 10 reasons to flip, The Phi Delta Kappan, 94(2) , 20-24.

Wikipedia, "Youtube,". the free encyclopedia. https://en.wikipedia.org/wiki/YouTube

Arikunto, S. (2013). Prosedur Penelitian: Suatu Pendekatan Praktik. Jakarta: Rineka Cipta.

Harahap, MS. (2018) "Meningkatkan Kemampuan Pemecahan Masalah Matematis dengan Penggunaan Bahan Ajar RME (Realistic Mathematic Education)", JURNAL EDUCATION AND DEVELOPMENT, vol. 3 , no. 2 , p. 56 